\title{
Acute Renal Failure in an Alcoholic Patient Taking Therapeutic Doses of Acetaminophen
}

\author{
Gregory L. Maze, MD, and Makau Lee, MD, PhD
}

Acetaminophen is a popular over-the-counter analgesic used for headaches and minor musculoskeletal pains. Most persons taking therapeutic doses of acetaminophen experience no side effects. When taken in greater than the recommended dosage, however, acetaminophen can cause serious complications, including liver and renal failure as well as death. ${ }^{1}$ This outcome is especially evident in those who take acetaminophen with suicidal intent. ${ }^{2}$

Although the pathogenesis of acetaminopheninduced hepatotoxicity is well known, the renal effects of acetaminophen have received less attention. Most reports have focused on the renal effects of large doses of acetaminophen, usually associated with severe hepatotoxicity or hepatic failure. ${ }^{3}$ There are, however, increasing numbers of reports of acetaminophen-associated renal failure in patients who have mild hepatotoxicity (without evidence of liver failure) caused by therapeutic ingestion or overdose. ${ }^{3-16}$ Additionally, 4 patients experienced acetaminophen-induced renal failure without any documented liver dysfunction. ${ }^{2,17,18}$ If renal failure can occur even with therapeutic doses of acetaminophen, then might there be certain persons predisposed to acetaminophen toxicity?

The aims of this paper are to present a case report of an alcoholic patient who developed renal failure after therapeutic doses of acetaminophen, to describe the types of patients possibly at risk of renal failure while taking acetaminophen, and to emphasize the importance of monitoring renal function while caring for patients taking acetaminophen either in therapeutic doses or overdose.

\section{Case Report}

A 41 -year-old man with a history of alcoholism was admitted to the hospital for hematemesis. He

Submitted, revised, 19 February 1997.

From the Department of Medicine (GLM, ML), University of Texas Health Science Center at San Antonio. Address reprint requests to Makau Lee, MD, PhD, Department of Medicine, University of Mississippi Medical Center, $2500 \mathrm{~N}$ State St, Jackson, MS 39216. had been well until 12 days before admission, when he drank 4 to 5 glasses of wine on that day. He began having flu-like symptoms for which he took approximately $5 \mathrm{~g}$ of acetaminophen during the next 3 days (ie, about 3 extra-strength or 500$\mathrm{mg}$ acetaminophen tablets each day for 3 days). Nine days before admission, he went to a local clinic complaining of intractable nausea and vomiting, and his condition was presumptively diagnosed as viral hepatitis because of elevated liver function tests. He was offered symptomatic treatment as an outpatient (ie, rest, plenty of fluids, and antiemetics, as needed). His nausea and vomiting continued for the next 8 days with one episode of hematemesis on the day of admission. During this period he also noticed a reduction in urine output.

His medical history was unremarkable, except for a history of regular consumption of 1 gallon of whiskey per week for the past 10 years. He denied intravenous drug abuse or uses of other prescription medications and over-the-counter drugs (such as aspirin).

When examined, his pulse was 97 beats per minute, his blood pressure was $117 / 76 \mathrm{mmHg}$ without orthostasis, and his temperature was normal. He had icteric sclera and spider angioma. His abdomen was soft and nontender, but his stool was guaiac-positive on rectal examination. Pertinent laboratory studies included a white cell count of $14,100 / \mu \mathrm{L}$, hemoglobin $10.4 \mathrm{~g} / \mathrm{dL}$, and hematocrit 30.5 percent. Prothombin and partial thromboplastin times were within normal limits, and serum albumin was $4.4 \mathrm{~g} / \mathrm{dL}$ (normal, $3.2-5.2 \mathrm{~g} / \mathrm{dL}$ ). Results of liver and renal function tests are summarized in Table 1. Calculated fractional excretion of sodium (based on urine and serum electrolytes obtained on hospital day 1) was 20.9 percent, which was consistent with oliguric acute tubular necrosis. Serologic tests for viral hepatitis for hepatitis A, $B$, and $C$ were negative. The remainder of serum chemistry results were within normal limits throughout the patient's hospitalization.

After the initial assessment, the patient was con- 
Table 1. Laboratory Results 9 Days Before and for 8 Days of Hospitalization.

\begin{tabular}{lcccc}
\hline $\begin{array}{l}\text { When } \\
\text { Measured }\end{array}$ & $\begin{array}{c}\text { Blood Urea } \\
\text { Nitrogen } \\
(\mathrm{mg} / \mathrm{dL})\end{array}$ & $\begin{array}{c}\text { Creatinine } \\
(\mathrm{mg} / \mathrm{dL})\end{array}$ & $\begin{array}{c}\text { Aspartate } \\
\text { Aminotransferase } \\
(\mathrm{U} / \mathrm{L})\end{array}$ & $\begin{array}{c}\text { Alanine } \\
\text { Aminotransferase } \\
(\mathrm{U} / \mathrm{L})\end{array}$ \\
\hline 9 days before admission & & 1.9 & 1590 & 4690 \\
Hospital & & & & \\
$\quad$ Day 1 & 135 & 14.3 & 63 & 316 \\
Day 2 & 142 & 10.5 & 55 & 156 \\
Day 3 & 125 & 7.9 & 56 & 135 \\
Day 4 & 95 & 5.9 & 73 & 117 \\
Day 5 & 64 & 4.2 & 114 & 141 \\
Day 6 & 43 & 3.2 & 119 & 146 \\
Day 7 & 31 & 2.8 & 105 & 149 \\
Day 8 & 23 & 2.4 & 81 & 133 \\
\hline
\end{tabular}

Normal values: blood urea nitrogen, $6-19 \mathrm{mg} / \mathrm{dL}$; serum creatinine, $0.5-1.2 \mathrm{mg} / \mathrm{dL}$; aspartate aminotransferase, $15-65 \mathrm{U} / \mathrm{L} ;$ alanine aminotransferase, $5-40 \mathrm{U} / \mathrm{L}$.

sidered to be hemodynamically stable, and his renal insufficiency and mildly elevated liver function tests were not contraindications for endoscopy. The patient underwent upper endoscopy and was found to have a Mallory-Weiss tear (a slit-like laceration of the gastric mucosa at the esophagogastric juction). With conservative management the patient had no recurrence of gastrointestinal bleeding. His renal and liver functions gradually improved during the next 5 days without the need for dialysis. He was discharged on hospital day 8 with a creatinine level of $2.4 \mathrm{mg} / \mathrm{dL}$ to a rehabilitation facility for continued therapy for his alcoholism. At a 1-month follow-up examination he was asymptomatic, and his creatinine level was 0.9 $\mathrm{mg} / \mathrm{dL}$.

\section{Discussion}

In the United States the overall incidence of acetaminophen hepatic and renal toxicity is not known. ${ }^{1}$ The incidence of renal failure after acetaminophen overdose is estimated to be 1 percent overall ${ }^{7}$ and 10 to 40 percent if the patient develops severe hepatic necrosis. ${ }^{19}$ An increasing number of case reports describe patients who have renal failure without liver failure, ${ }^{2-18}$ as well as 2 patients with normal liver function tests who had renal failure while taking therapeutic doses of acetaminophen. ${ }^{14}$

Acetaminophen toxicity most commonly causes elevated liver function tests. Elevated tests occur in two distinct groups of patients: (1) those with suicidal intent, and (2) those who accidentally overdose. ${ }^{1}$ The severity and clinical symptoms and signs of liver toxicity depend on the dose of acetaminophen ingested. Patients with serious suicidal intent usually take larger doses than those who accidentally overdose. Liver toxicity can occur after a single dose of 10 to $15 \mathrm{~g}$ of acetaminophen. ${ }^{20}$ Doses greater than $20 \mathrm{~g}$ of acetaminophen can be fatal. ${ }^{20}$

Clinically, acetaminophen hepatotoxicity has three phases (Table 2). ${ }^{20,21}$ First, gastrointestinal symptoms, such as nausea, vomiting, anorexia, and abdominal pain, appear in the first 24 hours. ${ }^{20} \mathrm{Sec}-$ ond, during the next 2 to 4 days, the gastrointestinal symptoms usually decrease and the liver function tests become elevated as a result of hepatic injury. Serum aminotransferase levels can reach $20,000 \mathrm{U} / \mathrm{L}$ or higher. Bilirubin increases only slightly. Clotting abnormalities can occur. ${ }^{21}$ Third, 3 to 5 days after ingestion, overt hepatic damage

Table 2. Three Phases of Acetaminophen Hepatotoxicity.

\begin{tabular}{|c|c|}
\hline Phase & Symptoms and Signs \\
\hline $\begin{array}{l}\text { One - initial } \\
24 \text { hours }\end{array}$ & $\begin{array}{l}\text { Gastrointestinal symptoms of nausea, } \\
\text { vomiting, anorexia, abdominal pain appear }\end{array}$ \\
\hline $\begin{array}{l}\text { Two }-2 \text { to } 4 \\
\text { days after } \\
\text { ingestion }\end{array}$ & $\begin{array}{l}\text { Gastrointestinal symptoms decrease, and } \\
\text { liver function tests become elevated from } \\
\text { hepatic injury. Serum aminotransferase } \\
\text { levels increase to } \geq 20,000 \text { U/L. } \\
\text { Bilirubin levels increase only slightly. } \\
\text { Clotting abnormalities can occur }\end{array}$ \\
\hline $\begin{array}{l}\text { Three }-3 \text { to } 5 \\
\text { days after } \\
\text { ingestion }\end{array}$ & $\begin{array}{l}\text { Overt hepatic damage occurs, and patient } \\
\text { might be jaundiced. Centrilobular necrosis } \\
\text { and sinusoidal congestion appear on liver } \\
\text { biopsy. Hepatic failure follows, with } \\
\text { hepatic encephalopathy and hemorrhagic } \\
\text { phenomena. If not treated, patient will die }\end{array}$ \\
\hline
\end{tabular}

Adapted from Insel ${ }^{20}$ and Zimmerman. ${ }^{21}$ 
occurs, and the patient can become jaundiced. Centrilobular necrosis and sinusoidal congestion appear on liver biopsy. Hepatic failure can follow with hepatic encephalopathy and hemorrhagic phenomena. ${ }^{21}$ If not treated, the patient generally dies.

Treatment consists of gastric decontamination and administration of activated charcoal within the first 4 hours, $\mathrm{N}$-acetylcysteine within 36 hours of ingestion with best results if given in less than 10 hours postingestion, and general supportive care (Table 3). ${ }^{20} \mathrm{~N}$-acetylcysteine binds the toxic metabolites of acetaminophen, resulting in inactivation and detoxification of these toxic substances.

As in acetaminophen-induced hepatotoxicity, renal toxicity is being seen more commonly in certain types of patients, such as those who are alcoholic, malnourished, or taking certain medications that can induce microsomal enzymes (such as phenytoin or isoniazid). ${ }^{22}$ Other causes of the renal failure, including hypotension, hypovolemia, infectious agents, nephrotoxic agents, heavy metals, rhabdomyolysis, and snake or spider bites, should be sought and treated. ${ }^{23}$ In this case, our patient did not experience hypotension or hypovolemia, as there was no evidence of orthostasis or shock. No infectious agents were ever identified. Our patient was not taking any known nephrotoxic agents other than acetaminophen, and there was no history of heavy metal exposure, rhabdomyolysis, or snake or spider bite. The temporal relation of the symptoms and the ingestion of acetaminophen gives the strongest evidence that the patient's renal failure was most likely related to the acetaminophen.

The pathogenesis of renal toxicity from acetaminophen remains unclear, but animal studies have provided a theoretical model for acetaminophen-induced renal injuries. ${ }^{24}$ To understand how the patient's alcoholism, according to this model, ${ }^{24}$ might have contributed to the development of the kidney failure even with the therapeutic doses of acetaminophen, it is necessary to understand the cytochrome P-450 system. Cytochrome P-450 enzymes of mostly the liver and to a lesser extent the kidney are involved in the conjugation of acetaminophen for excretion. In this process, however, toxic metabolites are formed that are detoxified by glutathione, which can be decreased in the malnourished person. ${ }^{22}$ In the alcoholic patient or those taking drugs that
Table 3. Treatment of Acetaminophen Overdose.

\begin{tabular}{ll}
\hline Timing & Treatment \\
\hline $\begin{array}{l}\text { Within first } \\
\text { 4 hours }\end{array}$ & $\begin{array}{l}\text { Gastric decontamination and administration } \\
\text { of activated charcoal }\end{array}$ \\
Within & $\begin{array}{l}\text { Administration of N-acetylcysteine. Best } \\
\text { results obtained if given less than 10 hours } \\
\text { postingestion. General supportive care }\end{array}$ \\
& $\begin{array}{l}\text { includes maintenance of fluids and electro- } \\
\text { lyte balance }\end{array}$ \\
\hline
\end{tabular}

Adapted with modifications from Insel. ${ }^{20}$

stimulate cytochrome P-450, the enzymes are elevated, which leads to an increase in the amount of toxic metabolite formed. The glutathione stores are quickly depleted, and the toxic metabolites attach to macromolecules on the cell membranes, causing the cell to die. ${ }^{10,15}$ Injury to the kidney is localized to the proximal tubules, correlating with the high concentration of cytochrome P-450 enzymes in this area. ${ }^{10}$

Blantz ${ }^{24}$ describes in a review article six conditions that can predispose a patient to increased acetaminophen renal toxicity: (1) severe, acute hepatic damage; (2) chronic hepatic disease; (3) male sex and advanced age; (4) concurrent stimulation of cytochrome P-450 enzymes; (5) chronic renal failure; and (6) other concurrent acute renal injuries, such as hypotensive injury or rhabdomyolysis. Thus, any condition that decreases the ability of the liver to metabolize acetaminophen effectively or increases cytochrome P-450 enzymes can potentially increase the amount of acetaminophen or its toxic metabolite reaching the kidney. $\mathrm{Cy}$ tochrome P-450 enzymes in the kidney are less able to detoxify acetaminophen compared with those in the liver; consequently, the renal glutathione stores are depleted more rapidly, and injury to kidney cells occurs as acute tubular necrosis. The injury is reversible with time, but the patient might require dialysis until renal function returns.

As mentioned, the natural history of acetaminophen-induced hepatotoxicity is remarkably consistent and predictable. $\mathrm{N}$-acetylcysteine, which inactivates the toxic metabolites of acetaminophen, can prevent liver injury from developing if administered during the first 36 hours of toxic ingestion. On the other hand, recent research suggests that the kidneys are not protected by $\mathrm{N}$ acetylcysteine in cases of toxic ingestion of acetaminophen. ${ }^{24}$ Patients with progressive renal failure 
will notice a decrease in urine output 4 to 7 days after toxic ingestion. In most reported cases patients were cautiously observed, and proper fluid and electrolyte balances were maintained during this time, but those patients with a more severe course occasionally required dialysis. $3,5,11$ Renal failure usually lasts less than 1 week, and renal function gradually returns to normal. There is no report in the literature of patient mortalities occurring without hepatic failure. Thus, the prognosis is good for acetaminophen-associated renal failure without severe hepatotoxicity.

In conclusion, the primary care physician needs to be cautious when caring for patients who are possibly at risk for liver and renal involvement even at low or therapeutic doses of acetaminophen. This case report describes one such patient. Alcohol is known to increase cytochrome P-450 enzymes, thus putting our patient at risk for toxicity even at therapeutic doses. If a patient is recognized to be at risk for acetaminophen toxicity, the physician can recommend another analgesic, educate the patient about acetaminophen, or use acetaminophen with caution while periodically monitoring renal and liver function.

\section{References}

1. Schiodt FV, Rochling FA, Casey DL, Lee WM. Acetaminophen toxicity in an urban county hospital. $\mathrm{N}$ Engl J Med 1997;337:1112-7.

2. Gabriel R, Caldwell J, Hartley RB. Acute tubular necrosis, caused by therapeutic doses of paracetamol? Clin Nephrol 1982;18:269-71.

3. Keaton MR. Acute renal failure in an alcoholic during therapeutic acetaminophen ingestion. South Med J 1988;81:1163-6.

4. Calvert LJ, Linder CW. Acetaminophen poisoning. J Fam Pract 1978;7:953-6.

5. Kleinman JG, Breitenfield RV, Roth DA. Acute renal failure associated with acetaminophen ingestion: report of a case and review of the literature. Clin Nephrol 1980;14:201-5.

6. Jeffery $W H$, Lafferty $W E$. Acute renal failure after acetaminophen overdose: report of two cases. Am J Hosp Pharm 1981;38:1355-8.

7. Cobden I, Record CO, Ward MK, Kerr DN. Paracetamol-induced acute renal failure in the absence of fulminant liver damage. Br Med J Clin Res Ed 1982; 284:21-2.

8. Curry RW Jr, Robinson JD, Sughrue MJ. Acute renal failure after acetaminophen ingestion. JAMA
1982;247:1012-4

9. Prescott LF, Proudfoot AT, Cregeen RJ. Paracetamol-induced acute renal failure in the absence of fulminant liver damage. Brit Med J Clin Res Ed 1982; 284:421-2.

10. Dabbagh $S$, Chesney RW. Acute renal failure related to acetaminophen (paracetamol) overdose without fulminant hepatic disease. Int J Pediatr Nephrol $1985 ; 6: 221-4$

11. Kaysen GA, Pond SM, Roper MH, Menke DJ, Marrama $M A$. Combined hepatic and renal injury in alcoholics during therapeutic use of acetaminophen. Arch Intern Med 1985;145:2019-23.

12. Pillans $\mathrm{P}, \mathrm{Hall} \mathrm{C}$. Paracetamol-induced acute renal failure in the absence of severe liver damage. S Afr Med J 1985;67:791-2.

13. Bjorck $S$, Svalander $C T$, Aurell $M$. Acute renal failure after analgesic drugs including paracetamol (acetaminophen). Nephron 1988;49:45-53.

14. Davenport A, Finn R. Paracetamol (acetaminophen) poisoning resulting in acute renal failure without hepatic coma. Nephron 1988;50:55-6.

15. Drenth JP, Frenken LA, Wuis EW, Van Der Meer JW. Acute renal failure associated with paracetamol ingestion in an alcoholic patient. Nephron 1994;67: 483-5.

16. Katzir Z, Baruch O, Hochman B, Biro A, Smetana S. Spontaneous remission of paracetamol induced acute renal failure. Clin Nephrol 1995;43:346.

17. Kher K, Makker S. Acute renal failure due to acetaminophen ingestion without concurrent hepatotoxicity. Am J Med 1987;82:1280-1.

18. Campbell NR, Baylis B. Renal impairment associated with an acute paracetamol overdose in the $\mathrm{ab}$ sence of hepatotoxicity. Postgrad Med J 1992;68: 116-8.

19. McJunkin B, Barwick KW, Little WC, Winfield JB. Fatal massive hepatic necrosis following acetaminophen overdose. JAMA 1976;236:1874-5.

20. Insel PA. Analgesic-antipyretic and antiinflammatory agents and drugs employed in the treatment of gout. In: Gilman AG, Rall TW, Niess AS, Palmer T, and Hardman JG, Limbird LE, et al, editors. Goodman and Gilman's the pharmacological basis of therapeutics. 9th ed. New York: McGraw-Hill, 1995.

21. Zimmerman HJ. Hepatic injury due to drugs and other chemicals. In: Chobanian SJ, Van Ness MM, editors. Manual of clinical problems in gastroenterology. Boston: Little, Brown, 1988.

22. McClain CJ, Holtzman J, Allen J, Kromhout J, Shedlofsky S. Clinical features of acetaminophen toxicity. J Clin Gastroenterol 1988;10:76-80.

23. Kumar S, Stein JH. Acute renal failure. In: Stein JH, editor-in-chief. Internal medicine. 4 th ed. St. Louis: Mosby, 1994.

24. Blantz RC. Acetaminophen: acute and chronic effects on renal function. Am J Kidney Dis 1996;28 (Suppl 1):S3-S6. 